Dr. Suchet, speaking from the bacteriological standpoint, said that experiments made so far proved that it was impossible to make any organism which was susceptible to penicillin, penicillinfast. There was no reason to believe that penicillin acted in the same way as did the sulphonamides, so that the experiment suggested by Lloyd Jones and Maitland was to be recommended.

One matter which was not known was the clinical level of penicillin which was efficient. All efforts to determine this had failed, and the level which was used and which was found as the result of bacteriological examination-and the blood level of penicillin could be determined only by bacteriological examination-was empirical. Investigation in the United States of America had shown that levels undetectable in the blood by means of bacteriological examination were nevertheless clinically effective and efficient. It would seem that to give these massive doses of penicillin, although the excretion was completed after 8-10 hours, would ensure that for many hours penicillin was present, although undetectable, and was doing some good in the body.

Work was being done on similar lines in other diseases and similarly good results were being obtained. It would seem that these 3-hourly or 4-hourly injections were given because a high blood level was expected, but that it might be unnecessary with penicillin.

Dr. B. Buckley Sharp agreed with Surg. Capt. Lloyd Jones on the advisability of providing a form of ambulatory treatment for syphilitic cases in civil life. It was all very well to say that the public must be educated into realizing that the disease was serious; but unfortunately absence from work entailed certification and inquiry from the patient's friends and relatives, and unless the public could be educated to believe that venereal disease was not a social stigma, he did not think that many civil patients would agree to go into hospital for a week or so for treatment.

Dr. C. P. Heywood said with regard to Dr. Lloyd's account of the Russian experiments, that the distinction was between re-infection and super-infection ; Dr. Lloyd had described a superinfection rather than a re-infection.

Surg. Lieut. Cdr. F. G. Maitland, in reply, said that a different dosage was given to each of the 3 separate groups of primary syphilis patients who were undergoing intensive treatment with arsenicals or with pencillin. He had recognized two types of jaundice and he thanked Prof. Beattie and Maj. Marshall for their collaboration and help in the treatment of this complication.

On the matter of late absorption and excretion of penicillin, there had been reports from the United States of America of methods intended to encourage these; but a few trials with wax and oil had not been satisfactory so far. In a conversation he had had with Sir Alexander Fleming, the latter had said he had had little experience with the oil and beeswax, as it was a quite recent innovation. Another method suggested was to delay the passage through the kidney ; but the promised drug had not arrived and so experimental work could not be carried out. With regard to the categories, he was pleased that this point had aroused interest.

Surg. Capt. T. R. Lloyd Jones, in reply to Col. Harrison, said that he hoped that his particular method of treatment would be of great help to the civil community; both Col. Harrison and Dr. Letitia Fairfield had referred in previous meetings to the difficulty of obtaining beds for venereal diseases patients, and it was felt that the method described would be a solution of this problem. When Mahoney started the treatment of syphilis with penicillin, there was doub concerning its efficiency, but this doubt had been removed; there might be doubt also about this new method of treatment with penicillin, but its results so far had been encouraging and time would prove its worth.

\title{
THE SUITABILITY OF KAHN ANTIGENS FOR THE TECHNIQUE USED IN THE CITOCHOL REACTION
}

\author{
By J. H. NELSON, M.Sc., Ph.D. (Dublin) \\ and H. SACHS, M.D., M.Sc., Ph.D. (Dublin) \\ Department of Bacteriology, School of Pathology, Trinity College, Dublin
}

: The present investigations have been carried out in order to discover whether or not Kahn antigens may be used in a similar manner to that employed for the citochol reaction (or Sachs-Witebsky reaction). Both antigens are distinguished by the high concentration of lipoids ; they differ in the mode of preparation.

Kahn antigen is obtained by extraction of dried beef heart powder with alcohol after preliminary treatment with ether ( $\operatorname{Kahn}^{1}$ and ${ }^{2}$ ), whereas wet minced beef heart is extracted for the citochol antigen with alcohol, the crude extract being then concentrated by evaporation (Sachs and Witebsky'). The sensitivity of the citochol reaction is secured by diluting the cholesterolized extract with 3 per cent sodium chloride solution in two stages (Sachs and Witebsky ${ }^{3}$ ). First, one part of the extract is quickly mixed with two parts of 3 per cent sodium chloride solution, then 9 further parts of the latter are rapidly added after 5 minutes interval. Thus a twelve-fold dilution is obtained, which is mixed with equal amounts of undiluted serum for the performance of the test. 


\section{TECHNIQUE USED IN THE CITOCHOL REACTION}

Sachs and Witebsky ${ }^{2}$ found that the citochol extract could be used to perform the Kahn test in the usual manner. (See also Haag and Linkweiler.) We are, however, unaware that Kahn antigens have been used in the technique adapted for the citochol reaction. As is well known, some newer rapid flocculation tests (for example those proposed by Eagle, Hinton, Ide, Laughlen and others) also make use of stronger salt solutions and some of them of higher dilutions of concentrated extracts, but they demand technical peculiarities in the preparation of the antigen and its dilution. Our experiments dealt only with the question as to whether or not the usual Kahn antigens might be used in higher dilution with 3 per cent sodium chloride solution and whether or not such a procedure had some of the advantages which are evident in the citochol reaction.

\section{Experiments with standard Kahn test}

To begin with, experiments were carried out with the standard Kahn test, the extract being diluted either with 0.9 per cent or with 3 per cent sodium chloride solution. Flocculation was often greater in the dilution with 3 per cent of salt, but the differences were not regular enough to be significant. When, however, higher dilutions of the Kahn antigen were made, in 0.9 and 3 per cent sodium chloride solution, the differences became very marked, as may be seen from Table 1 .

The dilutions of the Kahn antigen are as under.

-I. Standard dilution $(1: 2)$ with 0.9 per cent sodium chloride solution.

II. Standard dilution $(1: 2)$ with 3 . per cent sodium chloride solution.

III. Diluted $1: 2$ in 0.9 per cent saline and, after 10 minutes, made up to a $1: 6$ dilution with 0.9 per cent sodium chloride solution.

IV. Diluted $1: 2$ with 3 per cent sodium chloride solution and after 10 minutes made up to a $1: 6$ dilution with 3 per cent sodium chloride solution.

In our experiments 0.025 cubic centimetre of dilutions I and II were mixed with 0.15 cubic centimetre of serum, heated previously at $55^{\circ} \mathrm{C}$. for 30 minutes, and 0.1 cubic centimetre of dilutions III and IV was mixed with 0.1 cubic centimetre of heated serum. The results are shown in Table 1.

TABLE 1-FLOCCULATION OF KAHN ANTIGEN IN STANDARD $(1: 2)$ DILUTIONS AND IN $1: 6$ DILUTIONS

\begin{tabular}{|c|c|c|c|c|c|c|c|c|}
\hline \multirow{3}{*}{ Serum No. } & \multicolumn{4}{|c|}{ Standard $1: 2$ dilutions } & \multicolumn{4}{|c|}{$1: 6$ dilution } \\
\hline & \multicolumn{2}{|c|}{$\begin{array}{c}\text { I. } \\
\text { (with } 0.9 \text { per cent } \\
\mathrm{NaC1} \text { ) }\end{array}$} & \multicolumn{2}{|c|}{$\begin{array}{c}\text { II. } \\
\text { (with } 3 \text { per cent } \\
\mathrm{NaC1} \text { ) }\end{array}$} & \multicolumn{2}{|c|}{$\begin{array}{c}\text { III. } \\
\text { (with } 0.9 \text { per cent } \\
\mathrm{NaC1} \text { ) }\end{array}$} & \multicolumn{2}{|c|}{$\begin{array}{c}\text { IV. } \\
\text { (with } 3 \text { per cent } \\
\mathrm{NaCl} \text { ) }\end{array}$} \\
\hline & $\mathbf{a}$ & b & $\mathbf{a}$ & b & $\mathbf{a}$ & b & $\mathbf{a}$ & b \\
\hline 1 & - & ++ & + & +++ & - & - & ++ & +++ \\
\hline 2 & ++ & ++++ & +++ & ++++ & + & ++++ & ++++ & +++ \\
\hline 3 & ++ & $++t+$ & +++ & +++ & +++ & +++ & +++ & $++t$ \\
\hline 4 & + & +++ & ++ & $+++t$ & + & +++ & +++ & +++ \\
\hline 5 & - & - & - & - & - & - & - & - \\
\hline 6 & - & 一 & - & - & 一 & - & - . & - \\
\hline
\end{tabular}

$\mathrm{a}=$ reading after 3 minutes' shaking and addition of 0.5 cubic centimetre of 0.9 per cent saline.

$b=$ reading after incubation at $37^{\circ} \mathrm{C}$. overnight.

The number of + signs indicates the degree of flocculation.

\section{Experiments with diluted Kahn antigens}

From this it appears that a certain degree of reactivity is manifested by the $1: 6$ dilution of the Kahn antigen in 0.9 per cent saline, but that the sensitivity is greatly increased if the antigen is diluted in the same proportion with 3 per cent sodium chloride solution. Attention is called to the fact that in these conditions the immediate flocculation after shaking is very pronounced. (See column IV a, in Table 1.) It was found that twelve or even twenty times diluted Kahn antigens in $\mathbf{3}$ per cent sodium chloride solution could be used for the flocculation test. The twelvefold dilution appeared to be the most suitable, as in the citochol reaction. Whereas, however, the citochol extract is first of all diluted three times, it was necessary to 


\section{THE BRITISH JOURNAL OF VENEREAL DISEASES}

determine the optimal dilution in the first stage for every batch of Kahn antigen in order to obtain the best results. A representative example of many experiments is given in Table 2. The method used was as follows.

To 0.2 cubic centimetre of Kahn antigen were quickly added varying amounts of 3 per cent sodium chloride solution, as under.

Dilution I, 0.24 cubic centimetre ; II, 0.3 cubic centimetre ; III, 0.36 cubic centimetre ; IV, 0.4 cubic centimetre; $\mathrm{V}, 0.5$ cubic centimetre.

After 5 minutes' interval each dilution was made up to $1: 12$ by adding rapidly. 3 per cent sodium chloride solution.

TABLE 2-THE EFFECT OF VARYING THE PRIMARY DILUTION ON THE SENSITIVITY OF TWELVE-FOLD DILUTED KAHN ANTIGEN

\begin{tabular}{|c|c|c|c|c|c|c|c|c|c|c|}
\hline \multirow{3}{*}{$\begin{array}{c}\text { Serum } \\
\text { No. }\end{array}$} & \multicolumn{10}{|c|}{$\begin{array}{l}\text { Flocculation in mixtures of } 0.1 \text { cubic centimetre of serum and } 0.1 \text { cubic centimetre } \\
\text { of extract dilution (in } 3 \text { per cent } \mathrm{NaCl} \text { solution). }\end{array}$} \\
\hline & \multicolumn{2}{|c|}{ I } & \multicolumn{2}{|c|}{ II } & \multicolumn{2}{|c|}{ III } & \multicolumn{2}{|c|}{ IV } & \multicolumn{2}{|c|}{$\mathbf{V}$} \\
\hline & $\mathbf{a}$ & b & $\mathbf{a}$ & b & $\mathbf{a}$ & b & $\mathbf{a}$ & b & $\mathbf{a}$ & b \\
\hline 1 & $+t$ & + & $+t$ & $+t$ & $+t$ & $+t$ & + & + & - & - \\
\hline 2 & $+t$ & $+t$ & $+t$ & ++ & $+t$ & $+t$ & + & + & - & - \\
\hline 3 & ++ & ++ & ++ & $+t+$ & ++ & $+t$ & $+t$ & + & - & \pm \\
\hline 4 & $+t$ & $+t+t$ & $+t+$ & $+t+$ & $++t$ & $+t+t$ & $+t$ & + & - & $-t+t$ \\
\hline 5 & - & - & - & - & - & - & - & - & - & 一 \\
\hline
\end{tabular}

$a=$ reading after 3 minutes' shaking and addition of 0.5 cubic centimetre of 0.9 per cent saline. $\mathrm{b}=$ reading after incubation at $37^{\circ} \mathrm{C}$. overnight.

\section{Optimal conditions for dilution}

The experiment shows that the extract dilutions lose any sensitivity in respect of immediate flocculation after shaking if too highly diluted in the first stage; it shows too that the optimal conditions were obtained with dilution II, that is to say, by first diluting two parts of the antigen with three parts of 3 per cent sodium chloride solution. Thus the preliminary dilution is, in this example, somewhat lower than in the citochol reaction, in which the proportion is one part of citochol extract to two parts of 3 per cent sodium chloride solution. No general prescription, however, can be recommended for all Kahn antigens. The optimal primary dilution was in two cases $1: 1.5$, but with a third antigen it was $1: 0.9$ and with the fourth $1: 1$, when the antigens were finally used in twelve-fold dilution with 3 per cent sodium chloride solution. A fixed relation to the titre for the standard Kahn test could not be found; the titres for the 4 antigens, in their order as above, were, $1: 1 ; 1: 1.2 ; 1: 1 \cdot 1 ; 1: 1$.

The dilution of the antigen with 3 per cent sodium chloride solution is necessary for the procedure suggested. On using similarly either 0.9 per cent or 2 per cent sodium chloride solution for the twelve-fold dilution in two stages, we found the flocculation to be distinctly weaker.

The best method for performing the tests with twelve-fold diluted antigens is to mix 0.1 cubic centimetre of heated serum with 0.1 cubic centimetre of antigen dilution. After the tubes have been shaken for 3 minutes and the results read, 0.5 cubic centimetre of 0.9 per cent sodium chloride solution is added and the results are read again. Generally the second reading is sufficient; occasionally, however, a slight degree of flocculation may be more noticeable before the saline is added. In this way clear-cut results are obtained. A third reading after incubation for some hours gives information regarding the thermostability of the flocculi, but the special conditions at this stage do not justify recording the results as negative if the flocculi are dissoved on incubation.

\section{Advantages of dilution}

A special advantage of this technique is, just as in the citochol reaction, the fineness of the extract suspension, which is rather like an emulsion and shows sedimentation only after the lapse of time. The usual 1 cubic centimetre pipettes may be used without becoming clogged with coarse particles, as they do in the standard Kahn test, in which, according to $\mathrm{Kahn}^{2}$, one must " mix the antigen 


\section{TECHNIQUE USED IN THE CITOCHOL REACTION}

suspension frequently during the pipetting to assure a uniform mixture'. The flocculations are generally very distinct and easy to observe with the naked eye.

The consumption of antigen - and of serum-is also smaller than in the standard Kahn test, even if the latter is performed only with the medium dose $(0.025$ cubic centimetre). It may be further diminished by reducing the amounts of serum and extract dilution to the half, which can be done without any difficulty. The use of different volumes of the twelve-fold diluted antigen showed no improvement, as may be seen from Table 3 .

\section{Variations in results}

A greater amount $(0 \cdot 2$ cubic centimetre) of the twelve-fold diluted antigen may sometimes cause a greater degree of flocculation, but generally the medium dose $(0 \cdot 1$ cubic centimetre) is sensitive enough to give distinct results. On varying the amounts of serum it was found that 0.2 cubic centimetre of serum gave a lesser and 0.05 cubic centimetre of serum occasionally a slightly greater degree of flocculation than did $0 \cdot 1$ cubic centimetre. The modified method was carried out in connexion with the routine Wassermann and Kahn tests with very satisfactory results. In experiments performed in immediate comparison, out of 1,378 sera examined, 110 positive serum reactions were markedly stronger than in the standard Kahn test, 252 reactions were of the same strength, 6 reactions were weaker and 1,010 were negative in both tests. From our experience, therefore, we think the procedure worthy of trial.

TABLE 3-COMPARISON OF THE STANDARD KAHN TEST AND THE TEST WITH TWELVE-FOLD DILUTED ANTIGEN.

\begin{tabular}{|c|c|c|c|c|c|c|}
\hline \multirow{3}{*}{ Serum No. } & \multicolumn{6}{|c|}{ Flocculation in mixtures of } \\
\hline & \multicolumn{3}{|c|}{$\begin{array}{l}0.15 \text { cubic centimetre serum } \\
\text { and standard dilution } \\
(1: 2 \text { in } 0.9 \text { per cent } \mathrm{NaC} 1)\end{array}$} & \multicolumn{3}{|c|}{$\begin{array}{l}0.1 \text { cubic centimetre serum } \\
\text { and twelve-fold dilution } \\
\text { (in } 3 \text { per cent } \mathrm{NaC} \text { ) }\end{array}$} \\
\hline & $0.05 \mathrm{cc}$. & $0.025 \mathrm{cc}$ & 0.0125 cc. & 0.2 cc. & $0.1 \mathrm{cc}$. & $0.05 \mathrm{cc}$ \\
\hline 1 & + & + & ++ & ++ & ++ & + \\
\hline 2 & $+t$ & $+t$ & $++t$ & $+t+$ & ++ & + \\
\hline 3 & ++ & ++ & ++ & $++t+$ & $++t+$ & +++ \\
\hline 4 & ++ & $+t$ & ++ & +++ & $++t+$ & ++ \\
\hline 5 & + & + & + & + & $+t$ & ++ \\
\hline 6-10 & - & - & - & . - & - & - \\
\hline
\end{tabular}

Reading is after 3 minutes' shaking and addition of $0.5 \mathrm{cc}$. of 0.9 per cent $\mathrm{NaCl}$ solution.

\section{Summary and conclusions}

(1) Kahn antigens may be used in twelve-fold or even higher dilution if 3 per cent sodium chloride solution is used for diluting it in a similar manner to that in which citochol extracts are diluted for the citochol reaction. The antigen must be diluted in two stages; the degree of the first dilution depending upon the individual nature of the antigen.

(2) The experiments confirm the fact that in order to obtain rapid flocculation the concentration of the lipoids is not essential. It may be replaced by a more highly concentrated sodium chloride solution and appropriate dilution, which make the physical state of the extract lipoids suitable for quick flocculation.

(3) Many hundred of positive and negative sera were examined successfully and the method, which combines the use of Kahn antigens with the technique used in the citochol reaction, is recommended for general use. The advantages include the more homogeneous character of the extract suspension, thus making it easier to pipette, and the economy of material.

Thanks are due to the Medical Research Council of Ireland, which enabled us to carry out this work. We are very grateful also for the hospitality of the School of Pathology, Trinity 


\title{
THE BRITISH JOURNAL OF VENEREAL DISEASES
}

College, and for the facilities afforded by Professor Bigger and Professor O'Meara in the Department of Bacteriology.

\section{REFERENCES}

Haag, F., and Linkweiler, J. (1931) Z. ImmunForsch, 70, 337.

Kahn, R. L. (1925) Serumdiagnosis of Syphilis by Precipitation, Baltimore. - (1928) The Kahn Test, Baltimore.

Laughlen, G. F. (1935) Canad. med. Ass. J., 33, 179.

- (1938) Canad. publ. Hlth J., 29, 396.

Sachs, and Witebsky, E. (1928)1 Klin. Wschr., No. 26, p. 1233.

- $(1929)^{2}$ ibid. No. 5, p. 210.

- $(1931)^{3}$ ibid. No. 43, p. 1993.

\section{A RAPID MICROSCOPICAL METHOD FOR THE SERODIAGNOSIS OF SYPHILIS}

\author{
By M. SEILER, M.D. (Lwow) \\ Pathologist, Luton and Dunstable Hospital, Luton
}

Rappaport and Eichhorn described in 1943 a rapid test for the serodiagnosis of syphilis. In trying out this test I noticed that great reliability and accuracy can be achieved in an even shorter time by using the microscope for the estimation. In fact I believe that this method (known in this hospital as the S.S. (Serodiagnosis of Syphilis method) is more reliable than is either the Kahn or Wassermann reaction.

\section{Materials}

The materials required are as follows.

(1) Fresh beef heart antigen prepared with red-dyed mastic according to Rappaport and Eichhorn's method.

(2) Diluting fluid (disodium hydrogen phosphate, 5 per cent weight in volume).

(3) Glass capillary tubes of about 1 millimetre internal diameter and $4 \frac{1}{2}$ inches long. (These can be prepared easily in the laboratory.)

(4) S.S. tubes. These are prepared from glass tubing $1-\frac{8}{8}$ inch in diameter, by cutting pieces $4 \frac{1}{2}$ inches long, widening one end and sealing off the other.

(5) Glass slides.

(6) Glass square coverslips, No. 1.

\section{Method}

Preparation for microscopical examination.-Venous or capillary blood (or better still serum separated from the clot) is drawn into a capillary tube (as described in (3) above), so that three-quarters of the capillary are filled. The free end of the capillary, uncontaminated by blood or serum, is then sealed off in a flame, and the tube centrifuged for a short time until the cells are packed. After centrifuging, that part of the capillary which contains the packed cells is removed by cutting with a glass file.

One drop of the serum remaining in the capillary is introduced into the S.S. tube by tilting the capillary almost to the vertical position. (Cerebrospinal fluid is prepared according to the method described by Rappaport and Eichhorn, in two S.S. tubes.) To this drop of serum, a similar drop of antigen is added, the latter being vigorously shaken before use. The S.S. tube is now shaken for about $\frac{1}{2}$ minute, and finally a similar drop of the diluting fluid is added; the contents are then ready for microscopical examination, which can be carried out at any time within 24 hours.

Microscopical examination.-Immediately before examination, the contents of the S.S. tube are thoroughly shaken by tapping the bottom of the tube briskly about 10 times with the index finger.

One drop is poured out of the S.S. tube (gently to avoid air bubbles) on to a glass slide and covered with a microscopical glass square, No. 1. This wet preparation must be examined within 5 minutes, since drying may produce a false positive. 